\title{
REWARDS IN THE LEGAL SYSTEM: TENURE, AIRBAGS, AND SAFETY BINGO
}

\section{M.L. FRIEDLAND*}

Rewards are now used extensively in universities, industry; prisons and many other settings. The author argues that their use should be extended and that sanctions should not be so heavily relied upon. There is, for example. great scope for further exploration and experimentation with rewards in the area of traffic safery. Modest rewards combined with peer pressure may produce desired objectives in certain cases.

\section{TABLE OF CONTENTS}

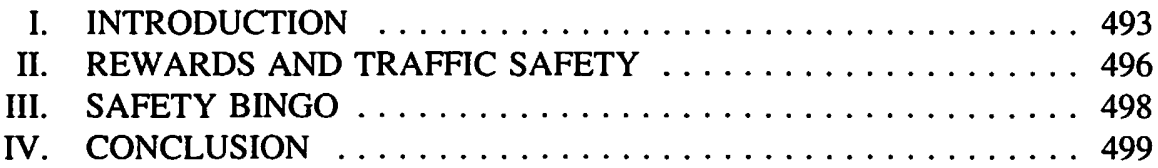

\section{INTRODUCTION}

Those of us from the academic community know the pervasiveness of the reward system. The delivery of this very comment will count in the reward structure in the Faculty of Law. Tenure, promotion, merit pay, prizes, and various other rewards, all influence our conduct. Even the possibility of a better office is a factor in some faculties, as we learned from Rod Macdonald's paper, "Office Politics," delivered at the last symposium.'

Similarly, businesses use rewards far more than sanctions to influence the behaviour of their employees. In a paper for a book of essays I edited, Sanctions and Rewards in the Legal System: A Multidisciplinary Approach, ${ }^{2}$ Hugh Arnold, a behavioural organization psychologist, observed that although "there is no doubt that punishment can and does have an impact on employee behaviour...there is emerging consensus that the effects of punishment on performance are not as strong as the influences of reward. ${ }^{13}$ The problem with punishment, he points out, is that it "has a tendency to create resentment, anger, and hard feelings toward the punishing agent and the organization in general" and "is effective only so long as the potential punishing agent or some independent monitoring device, is present to observe behaviour." 4 Thus it is no surprise to find that industry uses rewards in areas such as absenteeism, productivity, and occupational safety ${ }^{5}$ and that there is a major reward component in many management compensation schemes.

Faculty of Law, University of Toronto.

(1990) 40 U.T.L.J. 419.

M.L. Friedland, ed., Sanctions and Rewards in the Legal System: A Multidisciplinary Approach (Toronto: U. of T. Press, 1989).

3. "Sanctions and Rewards: An Organizational Perspective" in supra note 2 at 152.

lbid. at 142.

lbid. at 143-9.

See M.L. Friedland, M.J. Trebilcock \& K. Roach, Regulating Traffic Safety (Toronto: U. of T. Press, 1990) at 77. 
The same emotions of "resentment, anger, and hard feelings toward the punishing agent" identified by Arnold apply to attitudes towards the state as a punishing agent when the state overextends its power to discipline and punish. Punishment, particularly harsh punishment, may not achieve the compliance we want. As we move closer to a compliance-based model of enforcement, however, there will be greater emphasis on rewards. This is because, as Yale sociologist Albert Reiss has pointed out, "Where penalty systems primarily manipulate punishments, compliance systems principally manipulate rewards."7 The trend identified by Robert Howse and his colleagues in their earlier $\operatorname{paper}^{8}$ is therefore in line with the move towards compliance systems.

Historically, rewards were not widely used to control conduct. ${ }^{9}$ No doubt most English monarchs agreed with Machiavelli that "it is much safer to be feared than loved, if one of the two has to be wanting." 10 Bentham also took the view that if one had to choose one or the other, it is better to choose punishments than rewards. "By punishment alone," he wrote, "it seems not impossible but that the whole business of government might be carried on." " Note, however, that he added: "Though certainly not so well carried on as by a mixture of that and reward together." 12 This mixture is one of Robert Howse's main points with which I agree. The challenge is to creatively combine rewards with welldesigned sanctions. Sanctions have an important symbolic effect. The very existence of a law with a sanction will influence conduct, even if it is not actively enforced. Seat belt use increased significantly in virtually every jurisdiction where laws were enacted. ${ }^{13}$ Experience in Alberta shows this. In 1986, provinces with seat belt legislation had a use rate of 67.8 per cent, whereas Alberta had a rate of under 30 per cent. In 1987, the year after legislation was passed, Alberta's rate rose to 74.3 per cent and in 1988 to 82.5 per cent. $^{14}$

One of the few areas where the law has been using rewards for some considerable time is in the control of penal institutions. Persons who "behave" are given time off for good behaviour, a better chance for parole, and better accommodation. In the nineteenth century, tobacco was normally used as a significant reward as were better uniforms and facilities. ${ }^{15}$ Just last month I visited Attica penitentiary in New York State and one could easily see the widespread use of rewards in holding out the prospect of moving to other less restrictive institutions or to larger and less constricting cells within the same

7. A.J. Reiss, "Selecting Strategies of Social Control over Organizational Life" in K. Hawkins \& J.M. Thomas, eds., Enforcing Regulation (Boston: Kluwer-Nijhoff, 1984) 23 at 24.

R. Howse, J.R.S. Prichard \& M.J. Trebilcock, "Smaller or Smarter Government" (1990) 40 U.T.L.J. 498.

See generally, J.M. Beattie, "Criminal Sanctions in England Since 1500" in supra note 2 at 14; V. Aubert, In Search of Law: Sociological Approaches to Law (Oxford: Martin Robinson, 1983); A. Freiberg, "Reward, Law and Power: Towards a Jurisprudence of the Carrot" (1986) 19 Australia and New Zealand Journal of Criminology 91.

N. Machiavelli, The Prince (New York: Mentor Books, 1952) 98.

J. Bentham, Of Laws in General ed., by H.L.A. Hart, (London: Athlone Press, 1970) 135.

Ibid.

Supra note 6 at 33-34.

lbid.

See M.L. Friedland, The Case of Valentine Shortis (Toronto: U. of T. Press, 1986). 
institution. The use of rewards was, however, combined in the institution with the use of disciplinary charges (including solitary confinement), which could result in the deprivation of privileges.

Increasingly, governments have been using monetary rewards to encourage desirable conduct by criminal justice administrators: to the police for decreases in the crime rate; to localities to use probation rather than jail; and to district attorneys in New York City to cut down on long-term detainees awaiting trial. ${ }^{16}$ Rewarding success rather than punishing failure is not necessarily an obvious approach. Governments and university administrations often give extra funds to those who fail to meet budgetary and other objectives and take away funds from those who meet their objectives. Similarly, parents often give their best attention to the child who misbehaves.

One major problem with rewards in earlier periods was that the state had limited wealth to pay for them. Bentham referred to "the boundless expense it would require, and the absolute want of a fund from which that expense could be supplied." ${ }^{17}$ Blackstone also considered that the state lacked the resources for rewarding all law-abiding behaviour: "Were the exercise of every virtue to be enforced by the proposal of particular rewards, it were impossible for any state to furnish stock enough for so profuse a bounty."18 Today, however, the state has tremendous wealth. As Charles Reich stated in a major article in 1964: "Government is a gigantic syphon. It draws in revenue and power, and pours forth wealth: money, benefits, services, contracts, franchises and licenses. ${ }^{.19}$

Incentives tend to be used to get people to act often a defined, manageable group. It is usually more difficult to use incentives to prevent action (not stealing, for example) because everyone fits into that category except those who do the act. Still, as we will see in this symposium, giving rewards for not polluting is a feasible technique. Although some have expressed the view that "the law cannot reward a few in order to encourage the many,"20 in theory there is no reason why an exemplary reward (for example, selecting by lot one person to be grandly rewarded) cannot be given.

A major problem with rewards, however, which I hope will be addressed at the symposium, is the danger that the scheme will be abused and not properly monitored. The scientific research tax credit scheme which I did not see mentioned in any of the papers circulated in advance was one scheme to fall into this category. How can one design the scheme so that serious abuses do not occur? Evaluation", (Paper delivered at the Annual Law and Society Association meeting, Vail, Colorado, June 1988) [unpublished] "The results of these incentive-linked innovations are ambiguous." Supra note 11 at 289. 


\section{REWARDS AND TRAFFIC SAFETY}

My colleagues, Michael Trebilcock and Kent Roach, and I recently explored the question of rewards in the traffic safety area. ${ }^{21}$ Experimental programs have shown that rewards can increase the use of seat-belts. In the United States, psychologist Scott Geller conducted field experiments in various locations and was able to increase the use of seatbelts through voluntary compliance by means of small incentives at locations such as automotive plants, an army ammunitions plant, and naval shipyards. ${ }^{22}$ An incentive program at the General Motors Technical Center in Michigan, for example, influenced a 100 per cent increase in safety-belt wearing among 6,000 employees, from a 36 per cent baseline to an average of 70 per cent during the last month of the program, remaining at 60 per cent even before compulsory legislation. A recent article concludes: "Results across the various corporate-based studies showed that most gains from baseline to intervention periods exceeded 100 per cent, indicating that incentives work remarkably well to motivate safety belt use in industrial settings. ${ }^{23}$

The GM Technical Center program used a number of interesting techniques to motivate compliance. First, employees signed cards pledging to use seat-belts, a technique employed successfully by groups as diverse as fund-raisers and Alcoholics Anonymous. Second, card signers were eligible for a chance at sweepstake prizes (money and paid vacations). This raises the question whether it is better to get a sure, small prize or a chance at a larger prize. Finally, peer pressure was placed on the potential participants because the sweepstakes would not be held until a designated overall level of seat-belt use was achieved (at first, 60 per cent). ${ }^{24}$

More recent studies by Geller and his associates have, however, raised serious questions about whether incentives are as effective as educational sessions among groups of employees. ${ }^{25}$

Of course, the real solution to the problem of safety-belt use is to have automatic restraints, such as airbags and automatic belts. This is now a requirement in the U.S., although, in order to encourage airbag development, which is considered more desirable than automatic seat-belts, the National Highway Traffic Safety Authority (NHTSA) has extended until 1993 the period in which cars with a driver-side airbag and a manual seatbelt in the right-front passenger seat can meet the federal safety standard for automatic restraints.

\footnotetext{
21. Supra note 6.

22. lbid. at 81.

23. J.G. Cope, W.F. Grossnickle, \& E.S. Geller, "An Evaluation of Three Corporate Strategies for Safety Belt Use Promotion" (1986) 18 Accident Analysis and Prevention 243 at 250.

24. See R.J. Bonnie, "The Efficacy of Law as a Paternalistic Instrument" in G. B. Melton, ed., Nebraska Symposium on Motivation, 1985: The Law as a Behavioral Instrument (Lincoln: U. of Nebraska Press, 1986) 131 at 190.

25. See E.S. Geller et al., "Employer-Based Programs to Motivate Safety Belt Use: A Review of ShortTerm and Long-Term Effects" (1987) 18 Journal of Safety Research 1.
} 
Rewards for using airbags can come through government procurement contracts and through the insurance system. State Farm Insurance, for example, the largest U.S. vehicle insurance company, offered in 198810 per cent discounts for personal injury insurance for cars with automatic belts, 20 per cent for cars with driver air-bags, and 40 per cent for cars equipped with both airbags and automatic belts. Most major U.S. automobile insurers now offer similar substantial discounts for automatic restraints, one company giving a 60 per cent discount for premiums for medical payments for occupants plus additional incentives for driver and front-seat passenger airbags. ${ }^{26}$

As far as I am aware, no jurisdiction has legislation requiring that these discounts be given. In a state-run insurance scheme, such as is found in Quebec, B.C. and, as announced, in the near future in Ontario, discounts such as these can more easily and uniformly be given to encourage conduct.

A state-run system also makes it easier to adopt a uniform surcharge/discount system for causing accidents. This can be considered both a reward and a penalty system. British Columbia, for example, adopts a sliding scale for premiums, increasing the rate if there are culpable accidents and decreasing the rate each year the driver is claim-free. ${ }^{27}$ Quebec, on the other hand, has a state-run no-fault scheme for personal injuries, paid by a flat levy on drivers, and surprisingly, there is no experience rating ${ }^{28}$ Collision damage to one's own car is, however, handled by private insurance companies and coverage rates for this insurance will vary with accidents and violations.

We concluded our study of rewards in the traffic safety area as follows:

There is great scope for further exploration of and experimentation with rewards in driving. ${ }^{29}$ A government could, for example, introduce a scheme eliminating fees for licence renewals (either for the driver or the vehicle) for accident-free driving. Or, in a government-run insurance scheme, communities could be offered financial incentives if claims against the fund are less than a stated amount. Gerald Wilde suggested such a plan for the province of Saskatchewan (promising payments to young drivers as a group to the extent that they saved the government insurance scheme more than a stated amount), but it was never implemented. It has the advantage of an incentive with a certain degree of peer pressure. Safe driving could be linked with the provincial lottery. A province could, for example, give a violationfree or an accident-free driver one or more provincial lottery tickets every, say, three months. There are

27. See the Final Report of the Ontario Task Force on Insurance (Toronto: Queen's Printer, May 1986) (Chair: D.W. Slater).

28.

29.

Supra note 6 at 40

See supra note 6 at 69-70.

See, e.g., J.J. Donohue, "Using Market Incentives to Promote Occupant Safety" (1989) 7 Yale Law and Policy Review 449, arguing that governments should allow citizens the right to purchase the cost of not buckling-up (one rough estimate is $\$ 60$ per occupant per year). For a recent, somewhat pessimistic review of incentives for safe driving. compare Ontario Ministry of Transportation and Communication. Driver Improvement as Post-Licensing Control: The State of Knowledge by A.C. Donelson \& D.R. Mayhew (Toronto: Queen's Printer, 1987) 107-21. The report concluded (at 121) that the literature on rewards does "not offer clear directions for the development of nonpunitive approaches to driver improvement" but stated: "Nonetheless, the possibility that nonpunitive programs can improve driving performance among some sub-groups of drivers remains." 
a great number of possibilities that could be explored, using licence fees, insurance, lotteries, as well as cash payments, tax deductions or credits, public health-care premium reductions, and so on. What are particularly needed are more controlled experiments in which the efficacy of rewards can be more rigorously tested. ${ }^{30}$

\section{SAFETY BINGO}

Let me close with a discussion of "safety bingo." If we can understand why "safety bingo" apparently works, we will have gone a long way towards understanding incentivebased systems.

The Toronto Transit Commission (TTC) has won the American Public Transportation Association's (APTA) Safety Award for safe driving for twenty out of the last twentythree years. ${ }^{31}$ Its system of rewards for safe driving is likely part of the reason for this remarkable record. One obvious reward is winning the APTA award itself. Another is that the division (there are ten in Metro) with the best safety record receives the Silver Shield award. These rewards would probably not be enough to generate the TTC's record of safety. The TTC's safety program would seem to have been successful because of a competition - "Safety Bingo" - within each division. Each driver has a regular bingo card, and every day a new bingo number is drawn. As in regular bingo, the drivers start filling up their cards. The first driver within the division to get a line completed gets a small token prize, such as a tumbler. The first one to complete two lines gets a somewhat more elaborate prize, such as a flashlight. Completing three lines will win a toaster, and so on. There are also bonus prizes, such as black and white television sets.

Now comes the critical point. One accident by a driver that is that driver's fault, and causes the driver to be off work for more than that day, wipes out not only that person's bingo card but all the other bingo cards in the division. Everyone must start the game again with a clean card. So the person with the accident is letting down perhaps 300 other drivers, many of whom might have been close to winning a prize.

The technique, which is used by many companies with various modifications (for example, some use a game called "steeplechase" and some "safety poker"), combines a number of features that would seem to help decrease accidents. Perhaps most important, it gives drivers a reason for thinking about safety while they are driving. A recent study by a psychology instructor at the University of Waterloo has shown that even impaired drivers can drive more carefully if given a small incentive to do so. Vogel-Sprott tested the ability of legally impaired young drivers to operate a "tracometer" (a machine similar to the video games common today) when given twenty-five cents if they performed their task well. Impaired drivers given the monetary incentive performed on a par with a group that had been given a placebo in place of alcohol and no monetary reward. ${ }^{32}$ 
Peer pressure in the TTC's scheme adds an incentive to be careful. Some criticize the technique as a management gimmick to reduce compensation claims. (The TTC would have a particularly strong incentive to reduce claims because it must fully reimburse the Workers' Compensation scheme for every claim paid.) Terry Ison, former chair of the British Columbia Workers' Compensation Board, has written that such a program is "a gimmick type of safety program which creates incentives...for workers, to reduce recorded claims, possibly by creating peer group influence not to make a claim. ${ }^{.33}$ No doubt peer pressure operates in this way as well as in making workers more safety conscious, but overall, as in the case of drunk driving, peer pressure, when it can be directed to traffic safety ends, has an important potential to change behaviour.

The modesty of the actual rewards may in fact enhance the behavioural effect of the reward program. As psychologist Gerald Wilde, a leading advocate of rewards in driving, has stated:

The efficacy of relatively small incentives for road safety...may possibly be explained by reference to the theory of cognitive dissonance (Festinger 1964). If drivers can be induced to engage even temporarily - in new behaviour in order to earn an incentive, their attitudes and subsequent behaviour will change accordingly. The effects of such temporary commitments will be larger as the incentive or external justification offered is smaller. When the incentive is small, individuals themselves must justify their new behaviour so that it is consistent with the behaviour they are engaged in. ${ }^{34}$

Psychologist Scott Geller, another leading proponent of rewards, argues, with reference to B.F. Skinner, that rewards create a positive attitude in the driver: "Positive attitudes associated with a change in behavior maximize the possibility that the desired behavior will become a norm - the socially accepted rule of action. Positive attitudes are apt to follow incentive/reward techniques, since this positive reinforcement approach is generally perceived as 'voluntary' and does not elicit perceived threats to individual freedom." ${ }^{35}$

\section{CONCLUSION}

What can we learn from this discussion? Here are a number of points:

Rewards should be modest such that the individual that changes his or her behaviour or the corporation that changes its behaviour can believe that they were doing it because it was the right thing to do, not simply because of the reward. This will therefore affect future conduct.

(2) The reward system will be more effective if some form of peer pressure is also employed. To revert to the University example that started this comment, we find in universities not only individual rewards but peer pressure by one's colleagues

T.G. Ison, "The Significance of Experience Rating" (1986) 24 Osgoode Hall L.J. 723 at 726.

G.J.S. Wilde \& P.A. Murdoch, "Incentive Systems for Accident-Free and Violation-Free Driving in the General Population" (1982) 25 Ergonomics 879 at 887-8.

E.S. Geller, "Large Scalc Application of Behavior Analysis to Make a Difference" (1985)

Proceedings, American Psychological Association, Division 23, Consumer Psychology, 3. 
to produce because of the collective rewards that will come to the department or faculty.

(3) The existence of a law dictating a course of action, even with modest enforcement, can have a positive effect, as we saw in the seat-belt example.

(4) Rewards can, in many cases, be combined with the threat of sanctions. We should give greater thought to the way sanctions are used.

(5) The reward system requires a very careful design to prevent abuse by those who claim they are entitled to the benefit, as in the case of the scientific research tax credit.

(6) Controlled experimentation on the effectiveness of rewards would be desirable.

(7) Finally, I put forward the suggestion that there should be a further Law Reform Commission of Canada symposium on exploring techniques for "designing out ${ }^{136}$ the undesirable conduct by controlling the opportunity for wrongdoing. ${ }^{37}$ A classic example of this is the elimination of the lethal quality of natural gas, which significantly reduced the number of suicides. ${ }^{38}$ This is the airbag solution to the problem of seat-belt use. In the long-run controlling opportunities is probably the most important technique for achieving compliance with the law.

R.V. Clarke \& P. Mayhew, Designing Out Crime (London: H.M.S.O., 1980) 19.

See generally, M.L. Friedland, ed., Securing Compliance: Seven Case Studies (Toronto: U. of T. Press, 1990) at 6-7.

38. See R.V. Clarke \& P. Mayhew, "The British Gas Suicide Story and Its Criminological Implications" in (1988) 10 Crime and Justice: An Annual Survey. 